УДК: $349.2: 331$

https://doi.org/10.52058/2708-7530-2021-10(16)-247-258

Сахарук Ірина Сергї̈вна кандидат юридичних наук, доцент, доцент кафедри трудового права та права соціального забезпечення, Київський національний університет імені Тараса Шевченка, вул. Володимирська, 60, м. Київ, 01601, тел.: (044) 239-31-86, e:mail: sakharuk_iryna@knu.ua, https://orcid.org/0000-0002-9146-2491

\title{
ПРАВОВІ ОСНОВИ ЗАБЕЗПЕЧЕННЯ СВОБОДИ АСОЦІАЦЇ̈ ТА ДОСТУПУ ДО КОЛЕКТИВНИХ ПЕРЕГОВОРІВ ПРАЦІВНИКІВ ЦИФРОВИХ ПЛАТФОРМ В УКРАЇНІ
}

Анотація. Стаття присвячена дослідженню проблем реалізації права на свободу асоціації та ведення колективних переговорів у сфері гіг-економіки. Наголошено, що в Україні на сьогодні застосування трудової діяльності цифрових працівників перебуває поза межами правового регулювання. Здійснено аналіз проєктів законів, які передбачають можливості для правового регулювання роботи на платформах. Наголошено на важливості законодавчого врегулювання ознак трудових відносин для протидії тіньовій зайнятості у сфері цифрової економіки. Проаналізовано законодавчі ініціативи щодо врегулювання праці за участю цифрових платформ, які негативно вплинуть на правовий статус окремих працівників платформ, так як передбачають виведення їх 3-під сфери дії трудового законодавства. Встановлено, що такі працівники не зможуть реалізувати право на об'єднання у профспілки та стати учасниками соціального діалогу.

Проаналізовано особливості правового регулювання механізмів створення профспілок та ведення колективних переговорів, визначено можливості залучення до них працівників платформ. Обгрунтовано, що теоретично працівники платформи відповідно до українського законодавства мають право створювати профспілки, а потенційна профспілка працівників платформи може мати право на колективні переговори. Але на практиці таке право потенційно може бути оскаржене платформою, оскільки вони, як правило, не мають статусу роботодавців, а працівники платформи не вважаються найманими працівниками. Доведено необхідність трансформації інституту колективних переговорів, встановлення можливості залучення до них усіх осіб, які працюють. Проаналізовано приклади такої трансформації у зарубіжних країнах. Внесено пропозиції щодо вдосконалення трудового законодавства стосовно свободи асоціації та участі в соціальному діалозі працівників платформ.

\footnotetext{
3 Наукове дослідження проведено в рамках держбюджетної теми №0119U100306 «Соціально-правові засади збереження та розвитку трудового потенціалу України»
} 
Ключові слова: гіг-економіка, цифрові платформи, трудові гарантії, професійна спілка, свобода асоціації, колективні переговори, колективний договір, соціальний діалог.

Sakharuk Iryna Serhiivna PhD in Law, Associate Professor, Associate Professor of the Department of Labour Law and Social Security Law, Taras Shevchenko National University of Kyiv, 64/13, Volodimirska St., Kyiv, 01601, tel.: (044) 239-34-32, e-mail: sakharuk_iryna@knu.ua,https://orcid.org/0000-0002-9146-2491

\section{THE LEGAL BASES FOR ENSURING FREEDOM OF ASSOSIATION AND ACCESS TO COLLECTIVE BARGAINING OF DIGITAL PLATFORM WORKERS IN UKRAINE}

Abstract. The article is devoted to the research the problems of ensuring the right to freedom of association and to collective bargaining in gig-economy. It has been emphasized that most digital workers, irrespective of whether they work online or offline, are classified as self-employed. There are no legal grounds for the recognition of official employment relationships of platform workers in Ukraine nowadays.

The author has been conducted an analysis of draft laws that provide opportunities for legal regulation the labour on digital platforms. It was emphasized the importance of legislative regulation of labour relations to combat shadow employment in the digital economy. It was also analysed legislative initiatives concerning digital platforms, which will negatively affect to the legal status of platforms workers, as they provide their removal from the scope of labour legislation. It has been established that such workers will not be able to exercise their right to join trade unions and become participants in social dialogue.

It was studied the peculiarities of legal regulation the mechanisms of creation trade unions and collective bargaining. The possibilities of involving employees of platforms in them were determined. It was substantiated, that in theory, platform workers under the current Ukrainian legislation are entitled to form their unions and the potential union of platform workers may have the right to collective bargaining. But in practice, such a rule potentially might be challenged by platform companies, because they do not have the official standing as employers as well as platform workers are not considered as employees. Thus, to recognize the right to collective bargaining for platform workers in Ukraine, it is necessary to legally expand the institution of collective bargaining for all who works. It was analysed the examples of such transformation of collective bargaining relations in foreign countries. Has been made the proposals for improving the labour legislation, in particular, for ensuring freedom of association and access to collective bargaining of digital platforms workers.

Keywords: gig economy, digital platforms, labour guarantees, trade union, freedom of association, collective bargaining, collective agreement, social dialogue. 
Постановка проблеми. Трудова діяльність на цифрових платформах набуває все більшої популярності в світі. Науково-технічних прогрес, зокрема розвиток цифрової економіки, зумовлює розширення сфери застосування найманої праці, створення нових, - цифрових робочих місць. В Україні цифрова робота поширюється навіть дещо швидше, в тому числі, як наголошує М. Алексинська, через більшу економічну та політичну нестабільність, недостатне або неадекватне регулювання праці, погане правозастосовне законодавство [1, с.10]. Так, у 2013-2017 роках Україна посідала четверте місце у світі за розміром фінансових потоків та кількістю завдань, які виконуються працівниками на Інтернет-платформах (web-based platforms). При цьому, загалом щодо працівників платформ в Україні відсутня будь-яка статистика. Якщо проаналізувати відкриті дані лише трьох найбільших Інтернет-платформ (Freelancehunt.com, kabanchik.ua, Freelance.ua), тут зареєстровано понад 510 тисяч виконавців (станом на вересень 2021). Звичайно, одна особа може користуватись одночасно кількома платформами, не виконувати роботу постійно тощо, однак навіть вказана цифра показує значні масштаби поширення цифрової зайнятості. Тим більше, це дані лише 3 трьох платформ, а згідно з дослідженням МОП 2017 року, українські працівники працюють через понад 40 платформ, а також через різні групи в соціальних мережах [1, с.7].

Щодо платформ на основі місцезнаходження (location-based platforms) складно навести будь-яку, навіть неофіційну статистику, оскільки платформи вказану інформацію не розкривають. За оцінками експертів, кількість осіб, залучений до перевезення пасажирів на таксі або легковими автомобілями на замовлення, близько 220 тис. (станом на серпень 2020), 98\% з яких є неофіційно зайнятими фізичними особами, що не зареєстровані як суб'єкти підприємницької діяльності [2]. Вважаємо, що відсутність статистики, яка не дозволяє оцінити масштаби зайнятих на платформах в Україні, $є$ однією із важливих причин, чому питання врегулювання їх роботи не визначено сьогодні як стратегічне в межах державної політики у сфері праці.

Ключовим ризиком для осіб, що здійснюють трудову діяльність через цифрові платформи, є відсутність правового регулювання у цій сфері. Це зумовлює тінізацію відповідної зайнятості та відсутність будь-яких юридичних та соціальних гарантій для ії учасників. На практиці трудова діяльність на цифрових платформах в Україні регулюється фактично лише умовами самих платформ, які довільно застосовують юридичну термінологію, проте, по факту не вступають у будь-які правовідносини із користувачами власних послуг (ні в трудові, ні, за окремими винятками, в цивільно-правові). Співпрацю із користувачами послуг платформи маскують під інформаційні послуги [3, с.75]. Оскільки працівники цифрових платформ найчастіше $\epsilon$ самозайнятими особами, реєструються суб'єктами підприємницької діяльності або працюють неофіційно, на них не поширюються норми трудового законодавства. В тому числі, положення, які регламентують право на об'єднання в професійні спілки для захисту своїх 
соціально-економічних інтересів, а також право на ведення колективних переговорів. Відсутність можливостей для соціального діалогу із платформами та державою робить працівників цифрових платформ ще більш вразливими, соціально незахищеними, позбавляє значної кількості юридичних гарантій щодо колективно-договірного регулювання праці.

Аналіз останніх досліджень і публікацій. Більшість досліджень щодо платформенної роботи в Україні проводяться вченими-економістами. Тому, найчастіше акцент робиться на економічну складову роботи гіг-працівників, зокрема несплата податків (напр. О.В. Літорович [4]), а також часто відбувається підміна понять працівник, самозайнята особа, фрілансер (напр. див. О.О. Хандій [5, с.132]). Серед нечисленних досліджень роботи на цифрових платформах серед представників юридичної науки відсутній навіть єдиний підхід щодо можливого формату врегулювання їх праці. Так, існують пропозиції легалізації трудових відносин за допомогою конструкції запозиченої праці (О.С. Погорєлова [6, с.45]); створення нової категорії працівників платформ (Н.А. Азьмук [7, с.77]); створення спеціального правового регулювання праці працівників платформ із їх виключення зі сфери дії трудового права, але із наданням певного рівня правового захисту (Д.О. Новіков, О.М. Лук’янчиков [8, с.223]).

Слід відмітити, що існуючі правові дослідження щодо вдосконалення правового регулювання роботи працівників цифрових платформ не аналізують питання свободи асоціації та права на ведення колективних переговорів для них. Саме тому, метою статті $\epsilon$ аналіз національного законодавства 3 метою визначення юридичних можливостей для працівників цифрових платформ реалізувати право на свободу асоціації та на ведення колективних переговорів, а також внесення пропозицій щодо вдосконалення правового регулювання трудових відносин у цій сфері, в тому числі на основі зарубіжного досвіду.

Виклад основного матеріалу. В Україні, як наголошувалось вище, на сьогодні відсутні правові основи для визнання офіційних трудових відносин 3 працівниками цифрових платформ. Цей факт значною мірою ускладнює i можливості для останніх стати учасниками колективно-договірних відносин. Як наголошує М. Алексинська, такі проблеми є спільними для всієї Східної Свропи, хоча і є деякі винятки, принаймні з точки зору теоретичних основ створення профспілок працівників платформи [1, с.41].

В контексті можливої легалізації трудової діяльності працівників платформ позитивно слід відзначити проєкт Закону щодо визначення поняття трудових відносин та ознак їх наявності [9]. Так, проєктом пропонується алгоритм, згідно iз яким будь-які відносини, незалежно від їх юридичного оформлення, можуть бути визнані трудовими, якщо за своєю сутністю вони будуть відповідати хоча б трьом ознакам правовідносин, визначених проєктом як трудові.

Однак, є і досить негативні законодавчі ініціативи у сфері гіг-економіки. Так, у 2021 році прийнято Закон про стимулювання розвитку цифрової економіки в Україні [10]. Законом, зокрема, вводяться категорія гіг-контракт як цивільний 
договір, хоча, при цьому, його умови згідно закону відповідають ознакам трудових відносин відповідно до Рекомендації МОП 198 про трудове правовідношення та проєкту, вказаному вище. Незважаючи на наявність в законі окремих, обмежених соціальних гарантій для гіг-працівників, трудове законодавство на них поширюватись не буде. Також законом не визначається право гіг-працівників на об'єднання та право на колективні переговори.

Ще один проєкт закону стосується діяльності водіїв таксі [2]. Проєкт, фактично, передбачає легалізацію платформ на основі місцезнаходження (location-based platforms) як провайдерів інформаційних послуг, а водіїв як самозайнятих осіб, які будуть здійснювати діяльність на основі патенту. Звичайно, право на колективні переговори залишиться для тих водіїв, що будуть працювати в автомобільних перевізників - юридичних осіб. Проте, основна ідея реформи, згідно з позицією розробників - спростити умови ведення бізнесу для водіїв [11] (тобто, по факту, переведення більшості водіїв в категорію підприємців).

Незважаючи на те. що в переважній більшості працівники платформ не підпадають під сферу дії трудового законодавства, певні правові можливості для них щодо створення професійних спілок можна знайти в національному законодавстві. Так, щодо свободи асоціації, то відповідно до статті 1 Закону України «Про професійні спілки, їх права та гарантії діяльності» професійна спілка є добровільною неприбутковою організацією, яка об'єднує громадян, які мають спільні інтереси за родом професійної (трудової) діяльності або освіти [12]. Первинна організація профспілки визначається Законом як «добровільне об'єднання членів профспілки, які, як правило, працюють на одному підприємстві, в установі, організації незалежно від форми власності і виду господарювання або у фізичної особи, яка використовує найману працю, або забезпечують себе роботою самостійно, або навчаються в одному закладі освіти».

Таким чином, теоретично працівники платформи мають право створювати профспілки (оскільки здійснюють трудову діяльність, мають спільні інтереси у цій сфері), навіть якщо платформи не визнають їх найманими працівниками. При цьому, згідно статті 16 Закону України «Про професійні спілки, їх права та гарантії діяльності», професійна спілка легалізуються шляхом повідомлення на відповідність заявленому статусу, легалізуючий орган не може відмовити в легалізації профспілки, об'єднання профспілок. Права юридичної особи профспілка набуває з моменту затвердження статуту (положення), хоч і повинна пройти реєстрацію як юридична особа і на цьому етапі можуть виникнути певні труднощі для працівників платформ. Однак, навіть не пройшовши процедуру реєстрації як юридична особа профспілка може здійснювати свою діяльність після легалізації, а отже має повноваження для захисту своїх членів.

Щодо права на ведення колективних переговорів, то відповідно до статті 3 Закону України «Про колективні договори та угоди», колективний договір укладається між роботодавцеем і одним або кількома профспілковими органами, а 
у разі відсутності таких органів - представниками працівників, обраними i уповноваженими трудовим колективом 3 іншої сторони [13]. Тобто, потенційна професійна спілка працівників платформ теоретично може бути i стороною колективних переговорів згідно наведеного вище визначення.

3 іншого боку є ряд норм, які в сукупності дають привід сумніватись у наявності права та можливості профспілки працівників цифрових платформ брати участь у колективних переговорах та укладати колективний договір. В першу чергу тому, що ці норми пов’язують відповідні можливості із категорією працівники, тобто, згідно законодавства, осіб, які працюють за трудовим договором:

- відповідно до статті 1 Закону України «Про колективні договори і угоди», колективний договір, угода укладаються на основі чинного законодавства, прийнятих сторонами зобов'язань 3 метою регулювання виробничих, трудових $\mathrm{i}$ соціально-економічних відносин i узгодження інтересів працівників та роботодавців [13]. У статті 10 Кодексу законів про працю формулювання дещо інше: «Колективний договір укладається... 3 метою регулювання виробничих, трудових і соціально-економічних відносин і узгодження інтересів трудящих, власників та уповноважених ними органів» [14]. Але, в будь якому випадку реакція норми закону була прийнята пізніше КЗПП, тому застосовується вона;

- згідно статті 4 Закону України «Про колективні договори і угоди» право на ведення переговорів $і$ укладення колективних договорів, угод надається сторонам сочіального діалогу, склад яких визначається відповідно до законодавства про соціальний діалог. Відповідно до статті 4 Закону України «Про соціальний діалог в Україні», стороною соціального діалогу на локальному рівні визначено сторону працівників, тоді як на національному, галузевому, територіальному рівнях профспілкову сторону [15];

- на етапі прийняття колективного договору законодавством теж закріплено роль саме працівників. Так, відповідно до статті 13 Закону України «Про колективні договори та угоди», після схвалення проекту колективного договору загальними зборами (конференцією) трудового колективу він підписується уповноваженими представниками сторін не пізніш як через 5 днів 3 моменту його схвалення, якщо інше не встановлено зборами (конференцією) трудового колективу [13]. А відповідно до ст. 252-1 КЗПП, трудовий колектив підприємства утворюють усі громадяни, які своєю працею беруть участь у його діяльності на основі трудового договору (контракту, угоди), а також інших форм, що регулюють трудові відносини працівника з підприємством [14];

- відповідно до статті 9 Закону України «Про колективні договори і угоди», положення колективного договору поширюються на всіх працівників підприємств незалежно від того, чи є вони членами профспілки, i $\epsilon$ обов'язковими як для роботодавця, так і для працівників підприємства [13] (майже аналогічна норма у статті 18 КЗПП [14]). Тобто, якщо, наприклад, колективний договір буде укладено в інтересах працівників цифрової платформи, юридично його норми на останніх 
не поширюватимуться. Стосовно колективних угод формулювання дещо інше, відповідно до тієї ж статті Закону, положення генеральної, галузевої (міжгалузевої), територіальної угод діють безпосередньо і є обов'язковими для всіх суб'єктів, що перебувають у сфері дї̈ сторін, які підписали угоду.

Крім того, що законодавство регламентує можливість ведення колективних переговорів та укладення колективних договорів/угод працівникам, іншою стороною таких переговорів воно визначає роботодавця. А платформи статус роботодавця мають не завжди (особливо коли мова йде про Інтернет-платформи). Відповідно, можливість традиційних колективних переговорів та укладення колективних договорів для працівників цифрових платформ на сьогодні відсутня.

Що стосується колективних угод, тут нормативні положення сформульовано дещо по-іншому. За винятком статті 1 Закону «Про колективні договори та угоди», що визначає мету колективної угоди (регулювання виробничих, трудових i соціально-економічних відносин i узгодження інтересів працівників та роботодавців) [13], в інших випадках немає прив'язки до можливості ведення переговорів та укладення угод лише працівниками. Одночасно слід відмітити, що ведення колективних переговорів 3 метою укладення колективних угод значно складніше з огляду на питання репрезентативності та необхідність створення профспілок на територіальному, галузевому або національному рівнях.

Отже, для реального визнання права на ведення колективних переговорів для працівників платформ необхідно розширювати зміст інституту колективних переговорів за аналогією із регламентацією права створювати професійні спілки та права на страйк для усіх, хто працює (а не тільки для працівників, тобто осіб, що працюють за трудовим договором).

Трансформація уявлень про зміст колективних переговорів уже відбувається в деяких країнах. Наприклад, у 2018 році датська цифрова платформа послуг 3 клінінгу Hilfr та Об'єднана федерація датських робітників (3F) підписали історичну угоду, яка встановила гарантії у сфері праці та соціального захисту для працівників Hilfr [16]. Колективний договір визначив нову категорію працівників (the Super Hilfrs) паралельно 3 існуючими позаштатними працівниками (the Frelance Hilfrs). Будь-який працівник, який створив профіль на платформі Hilfr, починає як фрілансер, але після 100 годин роботи алгоритм платформи автоматично змінює його статус на статус працівника. На нього починає поширюватись профспілкова угода, яка передбачає пенсійні внески Hilfr, відпустку, допомогу по хворобі, а також значно вищу заробітну плату за колективною угодою. На початку 2019 року понад третина робіт з прибирання на Hilfr було забезпечено працівниками (the Super Hilfrs) [17]. Оцінка угоди на початку 2020 року показала високий рівень задоволеності роботою серед осіб, що отримали статус працівників, включаючи заробітки та захист, передбачені угодою. 3 точки зору платформи, угода покращила іiі видимість і брендинг як соціально відповідального суб'єкта [18].

Також профспілка 3F активно співпрацює з Wolt Workers Group (WWG), щоб 
захистити працівників платформи доставки їжі в Данії. Сторони, зокрема, вже домовились про підвищення заробітної плати та страхування водіїв від нещасних випадків з 2020 року, також 3F підтримала протест кур'єрів Wolt проти зміни моделі оплати, яка знизила мінімальну плату за короткі доставки та скасувала вихідні, бонуси за доставку [1].

У лютому 2021 року 3F та Торгова палата Данії (Dansk Erhverv) уклали загальнонаціональний колективний договір для кур'єрів 3 доставки їі (до 2023 року). Угода надає кур'єрам, зокрема, регульовану заробітну плату, пенсію та лікарняні, а також визнає їх договірні права [19].

Зміну підходів до традиційних колективних переговорів можемо спостерігати і на прикладі об'єднання працівників норвезької дочірньої компанії німецької компанії Foodora та Об’єднаної федерації профспілок Норвегії, які у вересні 2019 року (після п’ятитижневого страйку) підписали колективний договір. Він передбачає мінімальні контракти з кур'єрами (10 годин на тиждень), мінімальну заробітну плату, відшкодування витрат на обладнання, доплату в зимовий час тощо. На відміну від інших країн, кур'єри Foodora в Норвегії мають право вести колективні переговори та страйкувати [17, с.60]. Хоча статус кур'єрів значно відрізняється від стандартних трудових відносин у Норвегії, вони все ж мають значні соціальні гарантії, на відміну від працюючих на інших платформах.

Наведені приклади показують, що питання врегулювання мінімальних стандартів праці для працівників платформ імовірне, платформи можуть визнавати трудові відносини із такими працівниками та вести 3 ними колективні переговори. При цьому, значну роль у налагодженні соціального діалогу за участю платформ відіграють традиційні профспілки, якщо вони здійснюють активні дії для захисту працівників платформ.

Окремо слід відзначити недостатню ефективність соціального діалогу в Україні загалом. Часто колективні переговори мають формальний характер, а колективні договори лише дублюють норми законодавства. Як вказують експерти, положення і стан виконання Генеральних та галузевих угод свідчать про переважно формальне ставлення, в першу чергу з боку роботодавців та держави, як до укладання і змісту угод, так їх дотримання [20]. $Є$ проблеми і 3 реалізацією принципу свободи асоціації в Україні. Експертне опитування керівників профспілок різного рівня показало, що протягом 2015-2020 років 63,5\% 3 них стикались 3 проблемами дотримання та реалізації прав професійної спілки та/або прав профспілкових активістів [21, с.48].

Однак, працівники цифрових платформ очевидно готові до активних дій та ведення колективних переговорів із платформами. Так, починаючи із літа 2019 року періодично відбуваються протести та акції кур'єрів різних служб доставки в Україні (Glovo, UberEats, Dominos Pizza). 3 вересня 2021 року уже другий місяць триває страйк кур'єрів Bolt, які закликають до встановлення для них мінімальних трудових гарантій та протестують проти погіршення умов праці 3 боку платформи. Тому, враховуючи більш вразливе становище працівників платформ 
порівняно із працівниками, на яких поширюється трудове законодавство, відсутність будь яких соціальних гарантій, саме вони можуть стати рушійною силою виходу профспілкового руху та соціального діалогу в Україні на новий рівень.

Висновки. Виходячи 3 наявних викликів для реалізації трудових прав працівників цифрових платформ, в тому числі права на свободу об'єднання та на ведення колективних переговорів, політика для їх подолання повинна бути комплексною, включати як вдосконалення законодавства, так і налагодження соціального діалогу між зацікавленими сторонами. Досить важливо визначити правовий статус працівників платформ. Однак, незалежно від такого статусу, першочергово слід законодавчо гарантувати їм право на свободу асоціації та ведення колективних переговорів для можливості обговорення умов праці та реального впливу на політику платформ. Досвід зарубіжних країн також показує необхідність трансформації інституту колективних переговорів, надання можливості бути їх учасниками не лише суб'єктам, що мають статус учасників трудових відносин (працівникам та роботодавцям). Для цього потрібно внести відповідні зміни до законодавства, в першу чергу до Закону України «Про колективні договори та угоди».

В Україні необхідно посилювати інституційну спроможність професійних спілок, в тому числі для їх ефективної участі в соціальному діалозі на усіх рівнях. Традиційним профспілкам варто включити до свого порядку денного питання захисту працівників платформ незважаючи на відсутність у них юридичного статусу працівників. Тим більше, що позитивні приклади такої підтримки на сьогодні вже є в інших країнах. Також важливо об'єднати зусилля профспілок, представників платформ та експертів різних галузей для актуалізації питання врегулювання трудових відносин працівників платформ на державному рівні, розробці пропозицій такого врегулювання.

\section{Jimepamypa:}

1. Aleksynska M. Digital Work in Eastern Europe: Overview of Trends, Outcomes and Policy Responses, ILO Working Paper 32 (Geneva, ILO). 2021. 62 p.

2. Про внесення змін до деяких законів України щодо врегулювання діяльності з надання послуг з внутрішніх перевезень пасажирів на таксі та легковими автомобілями на замовлення: проєкт закону. URL: https://mtu.gov.ua/news/32088.html (дата звернення: 20.10.2021).

3. Сахарук I.C. Перспективи правового регулювання трудової діяльності працівників цифрових платформ. Науковий вісник публічного та приватного права. 2020. №6. С. $72-79$.

4. Літорович О. В. Аналіз ринку фрілансу в Україні. Вісник Національного університету “Львівська політехніка”. Серія “Проблеми економіки та управління”. 2020. №1. Т.4. С. 43-53.

5. Хандій О.О. Державна підтримка транформації трудових відносин в IT-сфері в умовах цифровізації економіки. Економіка промисловості. 2019. №2 (86). С. 126-145.

6. Погорєлова О.С. Напрями реформування трудового законодавства в умовах поширення цифрової роботи. Право та державне управління. 2020. №4. С.43-50.

7. Азьмук Н.А. Зайнятість через цифрові платформи - нова реальність сучасної економіки: виклики та стратегії адаптації. Економічний простір. 2019. №152. С.66-80. 
8. Новіков Д. О., Лук'янчиков О. М. Про перспективи трудового права в гіг-економіці. Проблеми реалізації прав громадян у сфері праці та сочіального забезпечення : тези доп. та наук. повідомл. учасників IX Міжнар. наук. практ. конф. (м. Харків, 11 жовт. 2019 р.) / за ред. О. М. Ярошенка. Харків : Право, 2019. С.220-224.

9. Про внесення змін до Кодексу законів про працю України щодо визначення поняття трудових відносин та ознак їх наявності: проєкт закону №5054 від 09.02.2021. URL: http://w1.c1.rada.gov.ua/pls/zweb2/webproc4_1?pf3511=71071 (дата звернення: 20.10.2021).

10. Про стимулювання розвитку цифрової економіки в Україні: Закон України від 15.07.2021. URL: http://w1.c1.rada.gov.ua/pls/zweb2/webproc4_1?pf3511=70298 (дата звернення: 20.10.2021).

11. Асоціація відповідальних перевізників опублікувала законопроєкт легалізації українського ринку таксі. НВ Україна. 09.08.2020. URL: https://bit.ly/3vLqUA9 (дата звернення: 20.10.2021).

12. Про професійні спілки, їх права та гарантії діяльності: Закон України від 15.09 .1999 зі змінами та доповненнями. URL: https://zakon.rada.gov.ua/laws/show/1045-14\#Text (дата звернення: 20.10.2021).

13. Про колективні договори та угоди: Закону України від 01.07.1993. URL: https://zakon.rada.gov.ua/laws/show/3356-12\#Text (дата звернення: 20.10.2021).

14. Кодекс законів про працю України від 10.12.1971 року зі змінами та доповненнями. URL: https://zakon.rada.gov.ua/laws/show/322-08\#Text (дата звернення: 20.10.2021).

15. Про соціальний діалог в Україні: Закон України від 23.12.2010. URL: https://zakon.rada.gov.ua/laws/show/2862-17\#Text (дата звернення: 20.10.2021).

16. Hale J. In Denmark, a historic collective agreement is turning the "bogus self-employed" into "workers with rights". Equal times. 04.07.2018. URL: https://www.equaltimes.org/in-denmark-ahistoric-collective?lang=en\#.YO79UOgzbIU (дата звернення: 20.10.2021).

17. Platform work in the Nordic models: Issues, cases and responses. Ed. by Kristin Jesnes and Sigurd M. Nordli Oppegaard. 2020. 106 p. URL: http://norden.diva-portal.org/smash/get/diva2: 1431693/FULLTEXT01.pdf. (дата звернення: 20.10.2021).

18. The Danish trade union 3F. Eurofond. 09.04.2021. URL:. https://www.eurofound.europa.eu/ sr/data/platform-economy/initiatives/the-danish-trade-union-3f (дата звернення: 20.10.2021).

19. What rights for gig economy workers in Ukraine? Emerging Europe, 04.02.2021. https://www.etf-europe.org/3f-secures-ground-breaking-national-sectoral-agreement-for-deliveryriders/ (дата звернення: 20.10.2021).

20. Павловський А. Проблеми соціального діалогу в Україні. Хвиля. 15.11.2018. URL: https:/hvylya.net/analytics/economics/problemi-sotsialnogo-dialogu-v-ukrayini.html (дата звернення: 20.10.2021).

21. Право на свободу об'єднань в професійні спілки як важлива складова захисту прав людини / А. Б. Блага, І. М. Кудінська, Г. О. Сандул, М. В. Щербатюк. Київ, 2021. 80 с.

\section{References:}

1. Aleksynska M. (2021). Digital Work in Eastern Europe: Overview of Trends, Outcomes and Policy Responses: ILO Working Paper 32. Geneva [In English].

2. Projekt zakonu Ukrai'ny Pro vnesennja zmin do dejakyh zakoniv Ukrai'ny shhodo vreguljuvannja dijal'nosti $\mathrm{z}$ nadannja poslug $\mathrm{z}$ vnutrishnih perevezen' pasazhyriv na taksi ta legkovymy avtomobiljamy na zamovlennja vid 4 serp. 2020 [On Amendments to Certain Laws of Ukraine on Regulation of Activities for Provision of Services for Domestic Transportation of Passengers by Taxi and motorcars per order from August 4 2020]. Retrieved from https://mtu.gov.ua/news/32088.html [In Ukrainian].

3. Sakharuk I.S. (2020) Perspektyvy pravovogo reguljuvannja trudovoi' dijal'nosti pracivnykiv cyfrovyh platform [Prospects for legal regulation of labor activity of employees of digital platforms]. Naukovyj visnyk publichnogo ta pryvatnogo prava - Scientific Bulletin of Public and Private Law, 6, $72-79$ [In Ukrainian]. 
4. Litorovych O.V. (2020) Analiz rynku frilansu v Ukrai'ni [Analysis of the Freelance Market in Ukraine]. Visnyk Nacional'nogo universytetu "L'vivs'ka politehnika". Serija "Problemy ekonomiky ta upravlinnja" - Bulletin of the National University "Lviv Polytechnic". Series "Problems of Economics and Management", 1 (4), 43-53 [In Ukrainian].

5. Khandiy, O. (2019). State support for the transformation of labour relations in the IT sphere in the context of digitalization of the economy [Derzhavna pidtrymka tranformacii' trudovyh vidnosyn v IT-sferi v umovah cyfrovizacii' ekonomiky]. Ekonomika promyslovosti - Industrial economics, 2(86), 126-145 [In Ukrainian].

6. Pohorielova O.S. (2020). Naprjamy reformuvannja trudovogo zakonodavstva $\mathrm{v}$ umovah poshyrennja cyfrovoi' roboty [The main aspects of reforming the labor law in the context of the spread of digital work]. Pravo ta derzhavne upravlinnja - Law and public administration, 4, 43-50 [In Ukrainian].

7. Azmuk, N. (2019). Zajnjatist' cherez cyfrovi platformy - nova real'nist' suchasnoi' ekonomiky: vyklyky ta strategii' adaptacii' [Employment through digital platforms is a new reality of today's economy: challenges and adaptation strategies]. Ekonomichnyj prostir - Economic space, 152, 66-80 [In Ukrainian].

8. Novikov D.O. \& Luk'janchykov O. M. (2019). Pro perspektyvy trudovogo prava v gigekonomici [On the prospects of labor law in the gig economy]. Proceedings from: Problemy realizacii' prav gromadjan u sferi praci ta social'nogo zabezpechennja: IX Mizhnar. nauk. prakt. konf. [Problems of realization of citizens' rights in the sphere of labor and social security: IX International. Science. practice. conference] (pp. 220-224). Harkiv: Pravo [In Ukrainian].

9. Projekt zakonu Ukrai'ny Pro vnesennja zmin do Kodeksu zakoniv pro pracju Ukrai'ny shhodo vyznachennja ponjattja trudovyh vidnosyn ta oznak i'h najavnosti vid 9 ljut. 2021 roku [On Amendments to the Labor Code of Ukraine to Define the Concept of Labor Relations and Signs of Their Existence from February 9 2021]. Retrieved from http://w1.c1.rada.gov.ua/pls/zweb2/webproc4_1?pf3511=71071 [In Ukrainian].

10. Zakon Ukrainy Pro stymuljuvannja rozvytku cyfrovoi' ekonomiky v Ukrai'ni : pryjnjatyj 15 lyp. 2021 roku [On stimulating the development of the digital economy in Ukraine from July 15 2021]. Retrieved from http://w1.c1.rada.gov.ua/pls/zweb2/webproc4_1?pf3511=70298 [In Ukrainian].

11. Asociacija vidpovidal'nyh pereviznykiv opublikuvala zakonoprojekt legalizacii' ukrai'ns'kogo rynku taksi [The Association of Responsible Carriers has published a bill to legalize the Ukrainian taxi market] (2020). НВ Україна. Retrieved from https://nv.ua/ukr/ukraine/events/taksi-mininfrastrukturiopublikuvav-zakonoproyekt-pro-legalizaciyu-rinku-taksi-novini-50104590.html [In Ukrainian].

12. Zakon Ukrainy Pro profesijni spilky, i'h prava ta garantii' dijal'nosti : pryjnjatyj 15 ver. 1999 roku [On trade unions, their rights and guarantees of activity from September 15 1999]. Retrieved from https://zakon.rada.gov.ua/laws/show/1045-14\#Text [In Ukrainian].

13. Zakon Ukrainy Pro kolektyvni dogovory ta ugody : pryjnjatyj 1 lyp. 1993 roku [On collective agreements and agreements from July 1 1993]. Retrieved from https://zakon.rada.gov.ua/laws/show/3356-12\#Text [In Ukrainian].

14. Kodeks zakoniv pro pracju Ukrai'ny [Code of Labor Laws of Ukraine] (1971, December 10). Retrieved from https://zakon.rada.gov.ua/laws/show/322-08\#Text [In Ukrainian].

15. Zakon Ukrainy Pro social'nyj dialog v Ukrai'ni : pryjnjatyj 23 grud. 2010 roku [On social dialogue in Ukraine from December 23 2010]. Retrieved from https://zakon.rada.gov.ua/laws/ show/2862-17\#Text [In Ukrainian].

16. Hale J. (2018) In Denmark, a historic collective agreement is turning the "bogus selfemployed" into "workers with rights". Equal times. Retrieved from https://www.equaltimes.org/indenmark-a-historic-collective?lang=en\#.YO79UOgzbIU [In English].

17. Jesnes K. \& Sigurd M. Nordli Oppegaard (Eds.) (2020). Platform work in the Nordic models: Issues, cases and responses. Denmark. Retrieved from http://norden.divaportal.org/smash/get/diva2:1431693/FULLTEXT01.pdf [In English]. 
18. The Danish trade union 3F (2021). Eurofond. Retrieved from https://www.eurofound.europa.eu/sr/ data/platform-economy/initiatives/the-danish-trade-union-3f [In English].

19. What rights for gig economy workers in Ukraine? (2021). Emerging Europe Retrieved from https://www.etf-europe.org/3f-secures-ground-breaking-national-sectoral-agreement-for-delivery-riders/ [In English].

20. Pavlovs'kyj A. (2018). Problemy social'nogo dialogu v Ukrai'ni [Problems of social dialogue in Ukraine]. Hvylja - Wave. Retrieved from https://hvylya.net/analytics/economics/problemisotsialnogo-dialogu-v-ukrayini.html [In Ukrainian].

21. Blaga A.B., Kudins'ka I.M., Sandul G.O. \& Shherbatjuk M.V. (2021). Pravo na svobodu ob'jednan' $v$ profesijni spilky jak vazhlyva skladova zahystu prav ljudyny [The right to freedom of association in trade unions as an important component of human rights protection]. Kyiv [In Ukrainian]. 